\title{
MODERATING EFFECT OF ORGANIZATIONAL SLACK ON ORGANIZATIONAL RENEWAL: THE DYNAMIC CAPABILITIES APPROACH
}

\author{
Bartłomiej J. Gabryś*
}

\begin{abstract}
Background. The idea behind the paper is to reconceptualise organizational renewal as a dynamic capability to reinterpret technologies, practices, beliefs in order to seize strategy by integrating, building and reconfiguring internal practices, processes, structures and systems as distinct organizational phenomenon. Proposed moderator - organizational slack seem to be relatively new concept when organizational renewal and organizational effectiveness are considered.

Research aims. Purpose of this article is to redeploy concept of organizational renewal to direct researchers' interest toward somehow neglected organizational phenomenon. Author believe that there is a critical gap in the previous studies, that have left opened door to new area for research by answering following research questions: What is an organizational renewal and how does it matter for organizational effectiveness? How indicated moderator - organizational slack - influence that process?
\end{abstract}

Methodology. Based on critical literature review new working definition of organizational renewal is proposed. Following inductive way of reasoning (Sprogoe \& Elkjaer, 2010) for new theory development four propositions were formulated based on the logic of predictive validity framework.

Key findings. Author integrates and systematizes disparate ideas to develop a cohesive theory of organizational renewal as dynamic capability with organizational slack as a moderator.

Keywords: organizational renewal, organizational effectiveness, organizational slack.

\footnotetext{
University of Economics in Katowice. E-mail: bargab@ue.katowice.pl
} 


\section{INTRODUCTION}

The organizational effectiveness is one of the crucial issues to organizations. It basically refers to the phenomenon in which some organizations are much more successful than others. It is also one of the most common issue addressed in empirical studies in strategic management field (Richard et al., 2009). In this context, long-term survival and success of an organization determined by its capacity for maturing without losing vitality, flexibility and fluidity - namely organizational renewal - should be understood as positively contributing to broadly conceived organizational effectiveness (including organizational performance and operating performance). In this vein, proposed construct of organizational renewal explain relationships between theoretical constructs - organizational renewal and organizational slack through propositions, which in future research should be tested at operational level on the road to increase the organizational effectiveness. This way of theorising is based on the logic of the two levels of predictive validity framework (Bisbe et al., 2007) - and throughout the paper I focus on first - conceptual one.

The basic idea behind the paper is to reconceptualise organizational renewal as a dynamic capability to reinterpret technologies, practices, beliefs in order to seize strategy by integrating, building and reconfiguring internal practices, processes, structures and systems as distinct organizational phenomenon meriting researchers' attention. Author believes that there is a critical gap in the previous studies, that have left opened door to new area for research. What is an organizational renewal and how does it matter for organizational effectiveness? How indicated moderator - organizational slack - influence that process?

Author believes that answer to these questions lies at the intersection of strategic management, corporate entrepreneurship and organization theory. Proposed moderator - organizational slack seems to be relatively new concepts when organizational renewal is considered. These concept already exists as separate constructs in strategic management and organization theory, but so far never been used in the context of organizational renewal as moderator per se. By proposing such an approach Author integrates and systematizes disparate ideas to develop a cohesive theory of organizational renewal, which represents a contribution to strategic management, change 
management, and organization and management theory. Overall, this study sheds new lights on why reinterpretation of technologies, practices and beliefs in order to seize already formulated strategy by integrating, building and reconfiguring internal practices, processes, structures and systems takes place in organizations and by doing so extends research on organizational effectiveness by providing additional understanding to a more general question how organizational antecedences may influences organizational effectiveness?

\section{RECONCEPTUALISING ORGANIZATIONAL RENEWAL - A NEW CONCEPT FOR RESEARCH}

The concept of "renewal" was first introduced into management studies by the end of 60 '. Starting from Gardner (1964) work on self-renewal, following authors (Haggerty, 1967, 1969) used the concept "renewal" to assert that the long-term survival and success of an organization is determined by its capacity for growing and maturing without losing the flexibility, fluidity, creativity and vitality as it was in the early days. With exception of few work published in 80', 90' and early 2000s the concept was somehow missing until special issue on "renewal" in 2009 by Agarwal and Helfat. They acknowledged that concept of renewal needs clarification much more deeper than dictionary based. From the perspective they implemented, renewal is a particular kind of strategic change, often described as refreshment or replacement ("it includes the process, content, and outcome of refreshment or replacement of attributes of an organization that have potential to substantially affect its long-term prospects" in Agarwal and Helfat, 2009, p. 282). Author believes that this perspective is a good starting point for conceptualizing organizational renewal for this specific theoretical paper purpose.

Using simultaneously replacement and renewal seems to be tricky, because it undermines the distinctiveness of renewal from organizational learning and change in general. It must be remembered, that one of the basic assumptions behind the paper is to distinguish organizational renewal from organizational change, but also innovation and learning processes. It should be study and identified as a distinct organizational phenomenon, as a process through which organization reinterprets former technologies, practices and beliefs for current use resulting in 
enhanced organizational performance. What is also worth to notice, organizational renewal (with its temporal and teleological dimensions) state it as a hermeneutical process whereby an organizations brings the past into the present by making historically situated interpretation. That gives a space for reinterpretations of their past in ways making it context-situated and actual from temporal perspective.

Managers responsible for organizational renewal are strongly embedded in symbolic and interpretative discourses defining organizational reality (like the process of knowledge sharing). They use symbolic as well cultural means on the road to create specifically formulated groups of organizational members. It is visible specially in analysing cause-effect relations, widespread metaphors or pictures of what is proper and wanted (like the picture of finance standing, pictures of success or failures). In domain of management research discourse analysis requires a deeper understanding of what text, practices or language artefacts means, not as a product of subjective or objective appraisal embedded in specific case, but more like a research material that manifest specific order of organizational knowledge concerning organizational members' activities. Reinterpretations requires learning (both from past and the present) on the road to combines both: retrospective and prospective logic (Gavetti \& Levithal, 2000). Unfortunately, up to date literature do not provide us with comprehensive understanding of that process - even though there are some discussions about traditionalism (Salipante \& Golden-Biddle, 1995), temporal orientations of the managers (Hurst et al., 1989) and organizational regenerations (Birnholtz et al., 2007). Specially the last one is in special interest to strategic entrepreneurship.

Concept of strategic entrepreneurship is one of the vital concepts to organizational entrepreneurship research (next to corporate venturing). Strategic entrepreneurship involves simultaneous opportunity seeking and advantage seeking behaviours (Ireland et al., 2003). The focal point of all strategic entrepreneurship forms involves innovation, that represents changes from the organization past structures, processes or capabilities. It can take one of five forms: strategic renewal (adoption of a new strategy); sustained regeneration (introduction of a new product into a pre-existing product category or introduction of an existing product into a new - to the firm - pre-existing market); domain redefinition (creation of new or reconfiguration of existing 
product categories or market space); business model reconstruction (design of a new or redesign of an existing business model); and finally in great importance to the paper - organizational rejuvenation (Morris \& Kuratko, 2008, p. 89).

Organizational rejuvenation is not synonymous to organizational renewal but include most of the constituting factors. It refers to entrepreneurial phenomena whereby the firm "seeks to sustain or improve its competitive standing by altering its internal processes, structures, and/or capabilities" (Covin \& Miles, 1999, p. 52). The objective of these efforts is to create "a superior organizational vehicle" through which the organizational strategy can be implemented. When successfully, there is no need for changes in strategy itself, offered products or services, or served markets. What is in great importance to organizational performance, innovations behind that process cannot simply imitate initiatives taken by other organizations in industry/sector.

The Resource Based View argue that the source of competitive advantage of the firm is based on resources that satisfy criteria of being simultaneously valuable, rare, imperfectly imitable and imperfectly substitutable (Kraaijenbrink et al., 2010). This theory explain how organizations, at least some of them, earn super-profits but do not address how future valuable resources can be created or how to renew the one already in possession. This is the concern of the dynamic capabilities approach (Ambrosini \& Bowman, 2009; Augier \& Teece, 2009). According to Barney (2001), this perspective share the same assumptions as resource based view and helps researchers and practitioners understand how resources in firm's possession evolves over time allowing organization to sustain its competitive advantage. This perspective focus organizational attention on the capacity how to create new resources or renew them (Teece, 2007; Rumelt et al., 1994). Moreover, Rindova \& Kotha (2001) argue that top management teams and its beliefs about organizational renewal might play an important role in developing dynamic capabilities.

The above mentioned arguments lead to the working definition what is understood as an organizational renewal:

Organizational Renewal is a dynamic capability to reinterpret technologies, practices and beliefs in order to seize strategy by integrating, building and reconfiguring internal practices, processes, structures and systems. 
Where: "technologies" are knowledge which is embedded in physical artefacts or codified in information sources, "practices" reflects actions imbedded with meaning within a social setting (Cook \& Brown, 1999) and beliefs are abstract knowledge (both declarative and transactive ones) referred to "know-what" and know-who" (Anderson, 1983), all of them are interrelated. This lead to first proposition:

Proposition 1: Organizational renewal is a dynamic capability construct indicated by practices, processes, structures and systems.

\section{ORGANIZATIONAL RENEWAL AND ORGANIZATIONAL PERFORMANCE}

Literature provide us with contrary views on renewal - performance relationships. As Agarwal \& Helfat (2009, p. 282) noticed "the fact that renewal has occurred tells us nothing about its contribution to profitability." This perspective is luckily seldom, and most of authors connotes (at least normatively) renewal to favourable performance outcomes. It is generally supported by Capron and Mitchell (2009) - linked to improved strategic fit (Volberda et al., 2001) - linked to sustainable competitive advantage (Kim \& Pennings, 2009) - to positive effect on entire sector (Leitch et al., 2010). Combs, Crook, and Shook, underline that the performance of the organization is a multidimensional concept and suggested that different dimensions are formative in nature and in consequence should be studied separately (2005).

Comparing the conceptualizations offered by prior research suggests three widely recognized dimensions of organizational performance and key indicators of each: growth, profitability, innovativeness. Since accounting measures of overall performance, such as return on assets, sometimes are not accessible, the subjective measures should be used as well. While financial performance goals are of particular type of goal, firms seek to meet aspiration levels on multiple goals (Gaba $\&$ Bhattacharya, 2012). From firm's competitive advantage point of view, comparisons with competitors reveal important information and enforce the possibility of effectively using subjective measures (Birley $\&$ Westhead, 1990).

It is important from the research perspective, that building a performance outcome assures that the connection to performance remains 
central to the renewal research agenda among moderating effect of organizational slack. This lead to following propositions:

Proposition 2: Organizational renewal is positively associated with organizational effectiveness as indicated by objective organizational performance indices.

Proposition 3: Organizational renewal is positively associated with organizational effectiveness as indicated by subjective organizational performance indices.

\section{MODERATION EFFECT OF ORGANIZATIONAL SLACK}

Early work in the area on why managers accumulate, maintain and deploy certain types of resources suggested that organizational slack directly impacts organizational performance (Bourgeois, 1981). However, for the last three decades related research has presented more conflicting perspectives on how organizational slack impact organization's performance. In some cases it buffers the firm from rapid changes (caused by external environments) (Bansal, 2003), enhances capacity to react to changes in consumer demand (Pfeffer $\&$ Salancik, 1986) or even sometimes leads to operational inefficiency (Singh, 1986). The role of industry seem to play important part of the relationship between organizational slack and performance (Wefald et al., 2010; Ferrier \& Lee, 2002; Porter, 1985).

In the broad context, maintaining organizational slack resources is good as long as it is used when dealing with unexpected demand or shifts in the availability of key resources and is considered to be a picture of what skilful management is (Tan \& Peng, 2003; Sharfman \& Dean, 1997). Nevertheless most managers reconcile organizational slack with negative perceptions in today's complex and dynamic environment (Latham \& Braun, 2008). Anchored in global economies recession, organizational slack is considered as an unnecessary and bringing extra costs to organizations, especially in the context of "downsize" or "rightsize" expected by shareholders. Moreover it is important to notice that, top management teams, as theory of political behaviour suggest, will influence perception not only of the level of organizational slack necessary in given conditions but also will decide 
what make specific resource to be considered as available, renewable or potential one. Figure 1 graphically depicts relationships between organizational slack and organizational effectiveness.

Level of organizational slack

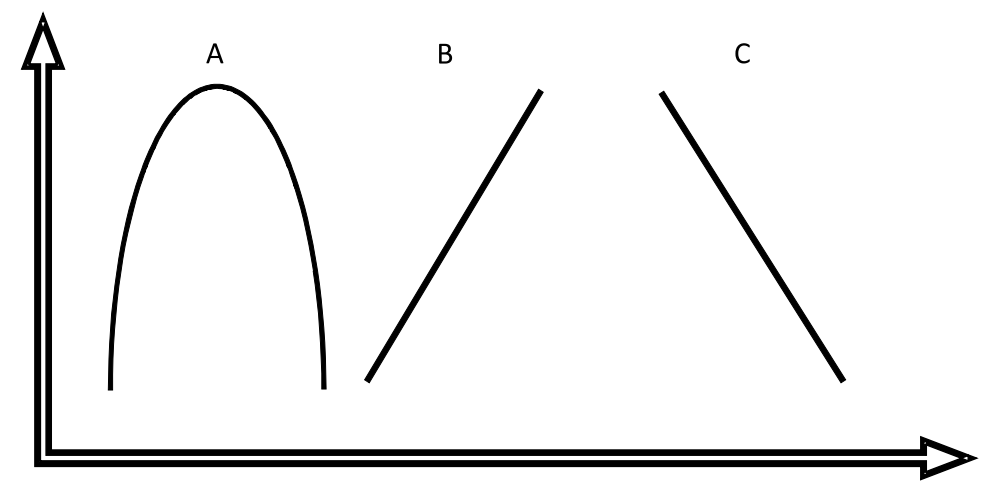

Figure 1. Relationships between organizational slack and organizational effectiveness - literature review results

Source: own elaboration.

The construct of organizational slack is consisted of three specific resources: available, renewable and potential ones. It stimulate strategic adjustment to environmental requirements, playing a role as a buffer for actual or potential technologies, practices or beliefs which organizational members' consider as required. It play a critical role in processes of organizational renewal and path created organizational change. These arguments lead Author to put organizational slack as a moderator on the relationship between organizational renewal and organizational performance and propose:

Proposition 4: Organizational slack influence the relationship between organizational renewal and organizational performance in such a way that it positively moderate until it reach maximum level pictured by reversed $U$ curve and negatively moderate after that level. 


\section{FUTURE RESEARCH - EFFECT OF ORGANIZATIONAL IDENTITY AND CHANGE}

Proposed definition of organizational renewal focus on reinterpreting, which could lead to renewal as an intentional process or an unintended implication of turning toward the organization's past as a basis for change. The technologies, practices and beliefs presently explored derive from their earlier forms and other sources of learning, so the basis for renewal must have undergone alteration or complete abandonment within the organization. Renewal and its implications can spill over from single group to entire organization, hence renewal applies at various levels of analysis which influence process of organizational identity.

Literature provide us with two basic streamlines of thought about organizational identity: namely social actor perspective and social constructionist perspective (Ravasi \& Schultz, 2006). First one, is based on functional properties of self-definitions (Friedland \& Alford, 1991), which guide individuals and organizations as social actors through continuity, coherence and distinctiveness (Whetten \& Mackey, 2002). Second perspective, focus on shared interpretative schemes, that members collectively construct in order to provide specific meaning to phenomena they experience (Gioia \& Thomas, 1996). Both perspective emphasize endurance of identity and resistance to the process of change, but in the case of social constructionist perspective. Frequently understandings are subject to renegotiations among organization's members.

Organizational identity is deeply reconciled with the problem of organizational flexibility in the process of organizational renewal (Nag et al., 2007). Changes in the organization's and relationships among its members are likely to require modifications to the way members interpret what is central and distinctive about their organization. Organizational changes will require members to actively reinterpret and develop new representations to symbolically characterize their organization (Fiol, 2002). Organizational identity is experienced by social actors embedded in organizational settings and provides lens for studding how organizational members gives meaning to their experiences during the process of renewal as a basis for individual and collective action affecting organizational performance. It is also a product of social communications where organizational 
members constantly negotiate thru interactions a shared symbolic representation of their organization that gives a sense of meaning to the organizational actions, objectives and existence (Gioia et al., 2000). It is definitely a wide area of future research in the context of multilevel research.

There is also remain question about role played by change and its effect on organizational renewal. Most of strategic management researchers use renewal and organizational change interchangeably (Burgelman, 1991; Simons, 1994; Sprogoe \& Elkjaer, 2010). They mostly highlights that renewal is reconciled with the "process" of change, "large scale" change, "corporate renewal" (Hart \& Berger, 1994) or adaptation (Floyd \& Lane, 2000). No doubt, renewal involves change, but at the moment researchers disagree about what the specific kind of change it include. Author believe that, renewal connotes path created change contributing to enhanced organizational performance.

Literature provide us with wide scope of typology of change. As generally suggested by Hodges and Gill (2015), it could be classified according to the magnitude (incremental, transformational or based on punctuated equilibrium), level (organization, team, individual), focus (strategic, operational) or the way how it is implemented (planned, emergent, contingency approach). Each of these dimensions pose different consequences for implementation of renewal processes. Most of literature model of renewal assume that organization will follow a path creation logic, combining to some level above mentioned types of change. Although the precondition of any path dependent or path created change is contingent, path dependent model might follow some more sophisticated logic specified by Sydow et al. (2009, p. 691): 1) Nonpredictability - indetermination of outcomes, 2) Nonergodicity more than one outcomes are possible, and that history selects among the alternatives, 3) Inflexibility - the member of organizations are lock-in in realized option, and shift to another is impossible (specially, after some period of time), 4) Inefficiency - members of organizations are locked with market solution which are implemented at the level of routines, structures and schemes.

Path creation is adding a value to the concept of path dependence by emphasizing agency and collectivities of multiple, component individuals or organizational actors in particular, who coordinate their activities with each other (Garud et al., 2010). By doing so, members of organization are capable to act-not only in reaction to environmental 
shocks, but also because of mindful deviations introduced by collectivities of actors. Path creation seems to be more favourable way of understanding organizational change but still behind it, exist a path, even when intentionally created, that show some level of irreversibility, momentum and possibly lock-in.

\section{DISCUSSION}

This paper is adding a value to existing literature (change management, strategic management, organizational and management theory) in two ways. It explicitly treat organizational renewal as separate phenomenon from dynamic capabilities perspective and describe how it influence organizational effectiveness. This approach satisfy prior call for research that will distinguish organizational renewal from organizational change or innovation process. Author believe that this clarified understanding can positively influence new theory-development efforts.

Paper suggest some important managerial implications. The logic behind understanding organizational renewal as dynamic capability foster a managerial orientations focused toward future competitive advantage based on renewal in the present. Considering renewal more deeply might increase organizational members' awareness of the possibilities for enhancing organizational effectiveness. Proposed moderators - organizational slack and organizational identity - play important roles in that process.

When organizational slack as moderator is considered - managers should be aware of various levels of different types of slack: available, renewable and potential and try to manage them effectively. It is generally recommended for the organizations to keep some organizational slack. It might secure some future behaviours to alleviate risk-adverse ones. It is also important from managerial perspective to stay alerted to actual size of organizational slack within organization, too much slack will lead to inefficient use of it, influencing organizational performance in specific and organizational effectiveness in general. Effectiveness might be also affected by created relaxed internal conditions conducting managers to decision making neglecting the best interest of the firm, so it might be necessary to reconsider access to organizational budget and the discretion allowed to managers to access funds within such budget. 
The empirical interest in the organizational slack construct is definitely increasing and urge researchers in the area of strategic management and management theory to employ multiple measurement tools and approaches. Because it is premature to advocate inclusion or exclusion of any specific measurement approach the process of assessing the convergence of objective and subjective measures will require construct validation process in different research settings to increase understanding of organizational renewal. Especially when construct's dimensions are considered: do they play similar or different roles. It is still a question that remain unanswered.

\section{CONCLUSIONS}

I make three key contributions in this paper. First, I draw from the literature the necessary constructs and perspectives which allowed to develop a thorough understanding of what organizational renewal is about. By doing so, I highlight what is within its scope and what makes it different to organizational change. Secondly, by critically reviewing existing literature, it provide new definition of organizational renewal from dynamic capability perspective, still being in the research vein of resource based view. Finally, I explain how proposed moderator, organizational slack, influence the relationship between organizational renewal and organizational effectiveness. It is emphasized that propositions are formulated based on the logic of predictive validity framework and they need operational testing.

\section{REFERENCES}

Agarwal, R. \& Helfat, C.E. (2009). Strategic renewal of organizations. Organization Science, 20(2), 281-293.

Ambrosini, V. \& Bowman, C. (2009). What are dynamic capabilities and are they a useful construct in strategic management? International Journal of Management Reviews, 11, 29-49.

Anderson, J.R. (1983). The Architecture of Cognition. Cambridge: Harvard University Press.

Augier, M. \& Teece, D.J. (2009). Dynamic capabilities and the role of managers in business strategy and economic performance. Organization Science, 20, $410-421$. 
Bansal, P. (2003). From issues to actions: The importance of individual concerns and organizational values in responding to natural environmental issues. Organizations Science, 14(5), 510-527.

Barney, J.B. (2001). Is the resource-based "view" a useful perspective for strategic management research? Yes. Academy of Management Review, 26, 41-56.

Birley, S. \& Westhead, P. (1990). Growth and performance contrasts between 'types' of small firms. Strategic Management Journal, 11, 535-557.

Birnholtz, J.P., Cohen, M.D. \& Hoch, S.V. (2007). Organizational character: On the regeneration of camp poplar grove. Organization Science, 18, 315-332.

Bisbe, J., Batista-Foguet, J.M. \& Chenhall, R. (2007). Defining management accounting constructs: A methodological note on the risk of conceptual misspecification. Accounting, Organizations and Society, 32(7-8), 789-820.

Bourgeois, L. (1981). On the measurement of organizational slack. Academy of Management Review, 6(1), 29-39.

Burgelman, R.A. (1991). Intraorganizational ecology of strategy making and organizational adaptation: Theory and field research. Organization Science, 20, 239-262.

Capron, L. \& Mitchell, W. (2009). Selection capability: How capability gaps and internal social frictions affect internal and external strategic renewal. Organization Science, 20, 294-312.

Combs, J.G., Crook, T.R. \& Shook, C.L. (2005). The dimensionality of organizational performance and its implications for strategic management research. In: D.J. Ketchen \& D.D. Bergh (eds.), Research Methodology in Strategy and Management. Oxford: Elsevier.

Cook, S.D.N. \& Brown, J.S. (1999). Bridging epistemologies: The generative dance between organizational knowledge and organizational knowing. Organization Science, 10, 381-400.

Covin, J.G. \& Miles, M.P. (1999). Corporate entrepreneurship and the pursuit of competitive advantage. Entrepreneurship Theory and Practice, 23(3), 47-63.

Ferrier, W. \& Lee, H. (2002). Strategic aggressiveness, variation and surprise: How the sequential pattern of competitive rivalry influences stock market returns. Journal of Managerial Issues, 14(2), 162-180.

Fiol, C.M. (2002). Capitalizing on paradox: The role of language in transforming organizational identities. Organization Science, 13(6), 653-666.

Floyd, S.W. \& Lane, P.J. (2000). Strategizing throughout the organization: Managing role conflict in strategic renewal. Academy of Management Review, $25,154-177$.

Friedland, R. \& Alford, R.R. (1991). Bringing society back in: Symbols, practices, and institutional contradictions. In: Powell, W.W. \& DiMaggio P.J. (eds.), 
The New Institutionalism in Organizational Analysis. Chicago: University of Chicago Press.

Gaba, V. \& Bhattacharya, S. (2012). Aspirations, innovation, and corporate venture capital: A behavioral perspective. Strategic Entrepreneurship Journal, 6, 178-199.

Gardner, J.W. (1964). Self-Renewal: The Individual and the Innovative Society. New York: Harper \& Row.

Garud, R., Kumaraswamy, A. \& Karnoe, P. (2010). Path dependence or path creation? Journal of Management Studies, 47(4), 760-774.

Gavetti, G. \& Levinthal, D. (2000). Looking forward and looking backward: Cognitive and experiential search. Administrative Science Quarterly, 45, 113-137.

Gioia, D.A. \& Thomas, J.B. (1996). Identity, image and issue interpretation: Sensemaking during strategic change in academia. Administrative Science Quarterly, 41, 370-403.

Gioia, D.A., Schultz, M. \& Corley, K. (2000). Organizational identity, image and adaptive instability. Academy of Management Review, 25, 63-82.

Haggerty, P.E. (1967). Corporate self-renewal. Management Decision, 1(4), 10-15.

Haggerty, P.E. (1969). Corporate self-renewal. Long Range Planning, 1(3), 9-15.

Hart, H. \& Berger, A. (1994). Using time to generate corporate renewal. International Journal of Operations \& Production Management, 14(3), 24-45.

Hodges, J. \& Gill, R. (2015). Sustaining Change in Organizations. London: Sage Publications.

Hurst, D.K., Rush, J.C. \& White, R.E. (1989). Top management teams and organizational renewal. Strategic Management Journal, 10(S1), 87-105.

Ireland, R.D., Hitt, M.A. \& Sirmon, D.G. (2003). A model of strategic entrepreneurship: The construct and its dimensions. Journal of Management, 29(6), 963-989.

Kim, H.E. \& Pennings, J.M. (2009). Innovation and strategic renewal in mature markets: A study of the tennis racket industry. Organization Science, 20, 368-383.

Kraaijenbrink, J., Spender, J.C. \& Groen, A.J. (2010). The resource-based view: A review and assessment of its critiques. Journal of Management, 36, 349-372.

Latham, S. \& Braun, M. (2008). The performance of financial slack during economic recession and recovery: Observations from the software industry (2001-2003). Journal of Managerial Issues, 20(1), 30-50.

Leitch, C., Hill, F. \& Neergaard, H. (2010). Entrepreneurial and business growth and the quest for a "comprehensive theory": Tilting at windmills? Entrepreneurship Theory and Practice, 34(2), 249-260.

Morris, M.H. \& Kuratko, D.F. (2008). Corporate Entrepreneurship: Entrepreneurial Development Within Organizations. San Diego: Harcourt College Publishers. 
Nag, R., Corley, K.G. \& Gioia, D.A. (2007). The intersection of organizational identity, knowledge, and practice: Attempting strategic change via knowledge grafting. Academy of Management Journal, 50(4), 821-847.

Pfeffer, J. \& Salancik, G. (1986). The External Control of Organizations. Marshfield: Pitman.

Porter, M. (1985). Competitive Advantage. Boston: Free Press.

Ravasi, D. \& Schultz, M. (2006). Responding to organizational identity threats: Exploring the role of organizational culture. Academy of Management Journal, 49(3), 433-458.

Richard, P.J., Devinney, T.M., Yip, G.S. \& Johnson, G. (2009). Measuring organizational performance: Towards methodological best practice. Journal of Management, 35, 718-804.

Rindova, V.P. \& Kotha, S. (2001). Continuous "morphing": Competing through dynamic capabilities, forms, and functions. Academy of Management Journal, 44(6), 1263-1280.

Rumelt, R.P., Schendel, D.E. \& Teece, D.J. (1994). Fundamental Issues in Strategy: A Research Agenda. Boston: Harvard Business School Press.

Salipante, P.F. \& Golden-Biddle, K. (1995). Managing traditionality and strategic change in non-profit organizations. Nonprofit Management \& Leadership, $6(1), 3-20$.

Sharfman, M. \& Dean, J. (1997). Flexibility in decision making: Informational and ideological perspectives. Journal of Management Studies, 34(2), 191-217.

Simons, R. (1994). How new top managers use control systems as levers of strategic renewal. Strategic Management Journal, 15, 169-189.

Singh, J. (1986). Performance, slack, and risk taking in organizational decision making. Academy of Management Journal, 29(3), 562-585.

Sprogoe, J. \& Elkjaer, B. (2010). Induction - organizational renewal and the maintenance of status quo. Society and Business Review, 5, 521-536.

Sydow, J., Schreyogg, G. \& Koch, J. (2009). Organizational path dependence: Opening the Black Box. Academy of Management Review, 34(4), 689-709.

Tan, J. \& Peng, M. (2003). Organizational slack and firm performance during economic transitions: Two studies from an emerging economy. Strategic Management Journal, 26(13), 1319-1334.

Teece, D. (2007). Explicating dynamic capabilities: The nature and microfoundations of sustainable enterprise performance. Strategic Management Journal, 26(13), 1319-1334.

Volberda, H.W., Baden-Fuler, C. \& van den Bosch, F.A.J. (2001). Mastering strategic renewal: Mobilising renewal journeys in multi-unit firms. Long Range Planning, 34, 159-178. 
Wefald, A.J., Katz, J.P., Downey, R.G. \& Rust, K.G. (2010). Organizational slack, firm performance, and the role of industry. Journal of Managerial Issues, 22(1), 70-87.

Whetten, D.A. \& Mackey, D. (2002). A social actor conception of organizational identity and its implications for the study of organizational reputation. Business and Society, 41, 393-414. 


\section{MODERUJĄCY EFEKT WPKYWU LUZU ORGANIZACYJNEGO NA EFEKTYWNOŚĆ ORGANIZACYJNA: PERSPEKTYWA ZDOLNOŚCI DYNAMICZNYCH}

Tło badań. Bezpośrednim przyczynkiem powstania artykułu jest chęć osadzenia na nowo w teorii nauk o zarządzaniu konstruktu odnowy organizacyjnej, definiowanej przez pryzmat zdolności dynamicznych jako umiejętność reinterpretowania technologii, praktyk, przekonań na drodze realizacji strategii poprzez integrowanie, budowanie i rekonfigurowanie wewnętrznych praktyk, procesów, struktur i systemów organizacyjnych. Zaproponowany moderator - luz organizacyjny - wydaje się nowa koncepcja w odniesieniu do odnowy organizacyjnej na drodze osiagania wysokiej efektywności organizacji.

Cel badań. Celem artykułu jest próba umiejscowienia konstruktu odnowy organizacyjnej w centrum zainteresowań badawczych, ze szczególnym naciskiem na próbę odpowiedzenia na pytania, czym jest odnowa organizacyjna oraz w jaki sposób wpływa na efektywność organizacji.

Metodologia. Opierając się na krytycznym przeglądzie literatury, wypracowano nową, roboczą definicję odnowy organizacyjnej. Wychodząc z założeń podejścia indukcyjnego do powstawania nowej wiedzy (Sprogoe \& Elkjaer, 2010), zaproponowano cztery twierdzenia wymagajace dalszej empirycznej weryfikacji.

Kluczowe wnioski. Zintegrowano i w dużym stopniu usystematyzowano dotychczas osobne konstrukty teoretyczne na drodze spójnej teorii odnowy organizacyjnej jako zdolności dynamicznej, w której luz organizacyjny odgrywa znaczącą rolę.

Słowa kluczowe: odnowa organizacyjna, efektywność organizacyjna, luz organizacyjny. 